\title{
University of Sydney
}

\section{Megan Le Masurier and Rebecca Johinke}

\section{Magazine studies: Pedagogy and practice in a nascent field}

\begin{abstract}
:
This essay considers the status of magazine studies as a cohesive and coherent discipline. We ponder why magazine studies, if considered at all, is usually conflated or elided with periodical studies and question whether this should be the case. We suggest that in addition to practical, methodological and disciplinary challenges (such as access to comprehensive searchable digital archives), and unlike periodical studies, magazine studies has been neglected because of associations with everyday culture and the feminine. We argue that magazine studies offers many rewards for scholars working in writing, literary and media studies and we offer up a case study of two of our postgraduate coursework units of study as examples of pedagogy and practice in a nascent field.
\end{abstract}

\section{Biographical notes:}

Dr Megan Le Masurier worked in the magazine industry as journalist and editor for many years and has been a lecturer in the Department of Media and Communications, The University of Sydney, Australia since 2006. Her current research areas are slow journalism, indie magazines, and magazines and everyday life. She can be contacted at: megan.lemasurier@sydney.edu.au

Dr Rebecca Johinke is a member of the Department of English, The University of Sydney, Australia. She is also the Director of Student Support Programs in the Faculty of Arts and Social Sciences. Her interests include creative non-fiction, magazines, Australian film and popular culture, and street narratives (from masculine car cultures to street cultures more generally), and she has a specific interest in the figure of the flâneur. She has taught writing and rhetoric for many years.

\section{Keywords:}

Creative writing - Magazines - Magazine studies - Periodical studies - Journalism studies - Teaching pedagogy 


\section{Introduction}

This article responds to Sean Latham and Robert Scholes's claim that because 'periodical studies' - a term we will interrogate - involves the study of texts that are by their very nature a collection (or storehouse) of varied texts like literature, journalism, advertisements, photography and visual art (including cartoons), it lends itself to collaborative research and writing practices (2006: 518). If magazines - not to be entirely conflated with periodicals - are themselves texts with multiple authors (editors, journalists, advertisers, illustrators, photographers, stylists and reader contributors) then a co-authored investigation of the genre has a certain logic (Latham \& Scholes 2006: 529). Thus, this article, written by two researchers and teachers of magazine studies at the University of Sydney, seeks to tease out what magazine studies is, or could be, in the Australian academy and how it might be best taught at a postgraduate level. Firstly, we explore some of the reasons why magazine studies remains a nascent field, and then we move on to discuss the practical pedagogical challenges that this lack of disciplinary coherence poses for us as teachers. Our case studies share our challenges related to compiling reading lists and creating assessment tasks that have scholarly rigour and relevance while being engaging for students studying in a field that is not yet established.

\section{Periodical studies}

We start this essay with the acknowledgement that there is a lack of disciplinary coherence in magazine studies. Indeed, the very existence of 'magazine studies' is more of a question than a reality. There is an established field called 'periodical studies', particularly strong in the US and the UK, that emerged from scholars involved in work on Victorian periodicals and modernist magazines. There are organisations and journals that reflect these interests, cluster work in the field and stimulate scholarly conversation and conferences. Victorian periodicals review (1968-) is, as the title suggests, a journal for work on the editorial and publishing history of periodicals from the Victorian era in Britain, Ireland and the Empire. The Journal of modern periodical studies (2010-) is interested in work on the 'little magazines' of the modern period, 1880 to 1950 . While both focus on periodicals, these scholars have had little to say to each other; they tend to be discrete sub-fields. American periodicals: a journal of history, criticism \& bibliography (1991-) publishes work from a wide range of scholars working on American magazines and newspapers. The overwhelming content in this journal, however, is historical. Not that there is anything wrong with that of course, but for students and scholars interested in more contemporary magazines, this journal is not an obvious port of call. And, its focus, as the title states is strictly American. There is also a Dutch language journal Tijdschrift voor tijdschriftstudies (Magazine for magazine studies) (1997-) with occasional articles in English and German. In English, however, there is no journal for magazine studies that could provide a scholarly home for the scattered work conducted across different disciplines in universities around the globe.

Like a number of other contributors to this special issue, we question whether periodical studies is where our research and teaching on magazines should be located. 
Likewise, we wonder whether magazine studies should be a field of its own. Should we bracket off magazines from periodicals - which is not a categorical distinction everyone will agree with - because 'periodicals' encompass newspapers, whereas 'magazines' do not? There are substantial differences in intention and social and cultural function between the publications that self-designate as newspapers, periodicals and magazines, that could justify treating magazines as a separate field for study. Or should magazines not be separated from periodicals because the latter is the categorical term for librarians who cluster magazines under the periodical banner? Should scholars compliantly agree with this order of things?

Lyn Pykett, writing about researching the Victorian periodical press, notes the 'double problem of defining the object of study, and devising an appropriate methodological framework' to conduct that study (1989: 100). Pykett argues that the study of periodicals is 'necessarily interdisciplinary', which challenges how fields of knowledge have been constituted so far, and how scholars have been trained. It is a relatively old essay now, but still useful in pointing to the methodological and disciplinary complexities of studying magazines. She also poses a very good starting point for thinking about magazine studies as a field (not that this is her concern):

it is not simply a question of what we need to know (and there is no escaping we need to know a lot), but it is also a question of how we need to know it, of what kinds of knowledge we need, what models we use, and what patterns we construct (101).

Judith Yaross Lee, in writing about the journal American periodicals and the future of periodical research, notes that 'periodicals differ substantially from other publications and that these differences call for new approaches to publications' history and criticism - approaches distinct from operations conducted as literary criticism or journalism history' (2008: 197). It is a point that David Abrahamson has also made with his concept 'magazine exceptionalism', that magazines are 'genuinely different' from other media forms (2007: 667).

Discussing the recent emergence of 'periodical studies', Latham and Scholes observe that many scholars have tended to view magazines 'merely as containers of information rather than autonomous objects of study' (2006: 517). Part of the problem in the development of the field, as they note, has been the sheer vastness of the archive and the logistics of time and place for scholars who have needed the material objects to work with. The digitisation projects for an increasing number of periodicals have radically changed the possibilities for research. (See, for example, Yale University Library's list of British and American Digital Periodicals or The Digital Archives Hub.)

In his introductory essay to 'Mapping the magazine' (2007), a special issue of Journalism studies (published the following year as a book), Tim Holmes suggests that another reason for the lack of a field of study for magazines is their diversity of subject matter, their long history and their protean nature. As he also writes, that very diversity of subject matter and the close connection magazines have to a community of readers provide scholars with an extraordinarily rich source for understanding particular social and cultural groupings as well as society and culture more broadly. One of the reasons Holmes offers for the lack of disciplinary focus is that 'a great deal 
more emphasis is put on presentation' of magazines as distinct from newspapers or books. This makes them more difficult to 'read' (2007: 511). This is a point we make in our case studies below, that teaching and researching magazines require a toolbox of methodological and disciplinary skills. Matthew Philpotts, in a recent article on the editors of literary journals, suggests that the fragmented field is partly due to entrenched disciplinary boundaries, 'not only between different national literatures, but also between the internal, qualitative readings privileged in more traditional literary studies and the external, predominantly quantitative approaches typical of the social sciences' (2012: 41). This is all true. Magazines are an extraordinary resource for the study of a vast range of issues, both historical and contemporary. They are indeed the 'storehouse' of our culture and society and have attracted the interest of scholars from many disciplines. The question here is whether there is anything to be gained by shepherding scholars interested in magazines, for possibly subsidiary reasons, together. Should the field be the medium or the area of interest that the medium has been used to represent?

All of the above arguments provide insights into the incoherence of magazine studies. Even so, these explanations for the slow and patchy emergence of a field do not feel quite adequate to us. The explanation may be more than practical, methodological or disciplinary. It is to do, we feel, with common understandings of how journalism is defined and valued, and also with gender.

The content of many magazines is the stuff of the private sphere, of leisure, everyday life, consumerism and popular culture, not the journalism of the Fourth Estate watchdogs or the more highbrow content and style of arts and literary magazines or journals. As members of the Fourth Estate, journalists have an idealistic and normative justification for their profession, to expose the uses and abuses of the powerful and to inform the public, especially in democracies (Deuze 2005). Magazine journalists do not have this function or justification - unless they write for news and current affairs magazines. The power of this normative discourse about what journalism is and should be has served to belittle and isolate the kinds of journalism produced by magazines; at least, to isolate it from serious scholarly attention. And yet, as Martin Conboy argues, magazine journalism contributes 'to other ways of knowing about the world beyond the narrowly political' (2004: 149). Journalism 'has always been constructed as a diverse and multiple set of textual strategies' and 'has always been broader than the specifically political'. In fact, journalism needed this multiplicity to survive (2004: 3). Because magazines are generally reliant upon advertising to be profitable, the assumption is that magazines primarily exist to deliver audiences to advertisers and therefore the independence of their entire content is compromised (McCracken 1993: 216; Steinem 1994: 133). It is a flawed argument. Newspapers are also run for profit and also require advertisers. The proliferation of supplements to the core news pages of newspapers since the 1960s was motivated by the need for niche advertising, a business model magazines had evolved in the late $19^{\text {th }}$ century (Damon-Moore 1994). Holmes describes this development in the newspaper business as a process of 'magazinification' (2007). Because magazinestyle journalism is not primarily concerned with the 'public interest' or the watchdog role of the Fourth Estate, it has suffered a lack of professional and political credibility. 
In the resulting hierarchy of journalisms, its status is lower than that of hard news. This is a professional reality and ideology that Liesbet van Zoonen has theorised in terms of gender - hard, public sphere topics are figured as masculine; soft, private sphere topics are figured as feminine, and thus of lower status (1998a; 1998b). And yet, as second wave feminists understood so well, it is in the private sphere where many important political issues are thought and fought about.

Moreover, despite the point that Sammye Johnson (2007: 523) makes about lack of scholarly access to industry research and the very good argument that Latham and Scholes put forward about access to comprehensive searchable archives having been the primary impediment to the growth of the field, we would argue that gender and the separation of the public and the private (domestic) is at least as important (2006: 518). The culture of everyday life - cooking, housekeeping, child rearing, relationship management, caring duties, consumption - has been clearly coded as low status 'women's business'. Indeed, the status of journalism and exactly what separates journalism from 'magazine-style journalism' and advertising and marketing or public relations is a significant one. The rhetorical implications of the conflation of editorial and advertorial makes for a fascinating area of study in consumer (glossy) magazines, but a case could be made that it is even more interesting in custom magazines. If there is a hierarchy between 'real' (news) journalism and 'magazine-style' journalism then the faux 'magazine-style' journalism written purely as a public relations exercise for a magazine like the Fitness first magazine would supposedly lie at the bottom of the hierarchy. As we have already noted, van Zoonen has written extensively about both of these issues and the rhetoric of 'decline' that is employed when discussing women's magazines and all forms of popular culture that are perceived as 'feminine' and therefore low status (1998a: 125). It is an argument Andreas Huyssens also makes in his analysis of 'mass culture as woman', 'that mass culture is somehow associated with woman while real, authentic culture remains the prerogative of men' (1986: 47). Magazine journalism, and magazines themselves, while not always about or for women, have inherited this association with the feminine, especially when positioned against 'hard masculine' news reporting.

One of the scholars we both return to for sustenance when thinking about the value of studying magazines and different kinds of journalism is John Hartley. He has an enduring respect for the lives and lifestyles of the non-elite and an intellectually sophisticated way of appreciating popular media, and especially magazines (see, Popular reality, 1996). When it comes to the media, and journalism in particular, Hartley identifies a sector of media workers as 'the smiling professions', which of course includes many who work in magazines. He states:

The smiling professions include all those who interface with the public in the name of pleasure, entertainment, attractiveness, appeal. They are the ones who extend the reach of media, who teach audiences the pleasures of staying tuned, who popularize knowledge. They are routinely despised by serious journalists (Hartley 2000: 40).

The smiling journalists are not the combative interviewers shining light into dark corners, exposing corruption and abuses of power. Their terrain is that of everyday 
life, pleasure, entertainment, consumption. As Hartley would put it, this is journalism that contributes 'to the micro-meaningfulness of everyday life' (1999: 19).

This division between public and private, between frowning and smiling media if you like, could be viewed as an almost atavistic hangover from an old Left, and Right, contempt for mass culture and a patronising elitist concern for the people who engage with it. This, of course, affected the way culture was taught and researched in the academy. Mainstream magazines were seen as too commercial, too advertisingdriven, too concerned with entertainment, consumption and lifestyle - basically they were seen as either the ideological running dogs of capitalism or a dumbed down popular distraction from the eternal truths and beauties of high culture. Women's magazines added gender oppression to the mindless capitalist stew, which sparked a tradition of feminist scholarship in magazines. We are caricaturing the positions, somewhat, and this is old news now. The development of cultural studies, media studies and the study of popular culture in the humanities has provided a strong counter-discourse to this older disdain for mass culture. But we have often thought that a residue of this attitude might partly explain why magazine studies has been slow to develop as a distinct scholarly field, both in Australia and elsewhere, and why Victorian and Modernist periodical studies, having a more highbrow lineage, have longer and stronger traditions of scholarship.

\section{Case studies}

The School of Letters, Art, and Media at the University of Sydney is one of the few schools in Australia that offers postgraduate coursework units in magazine studies, and our case studies centre on two units designed for literature, creative writing, media and publishing students in that school. At the time we first taught our units in 2007, to our knowledge there were very few universities in Australia offering specific courses in magazines. Journalism courses abounded, but courses that focused on magazines themselves - as a distinctive form of media involving concept, editing, commissioning, written content, graphic design, visuals, marketing, advertising ... all the very specific elements of magazine media beyond the journalism - did not exist, not to mention the lack of more scholarly courses on magazine history or magazine studies. Having said that, there is a fine Master of Publishing and Communications offered by the University of Melbourne, ${ }^{1}$ but, as we understand it, even that does not offer students the opportunity to make their own magazines or explore the history of the medium. The situation is different in the US and the UK, where there are many postgraduate courses on magazines. At Columbia University Graduate School of Journalism in New York, for example, the Columbia Publishing Course is an intensive six-week summer course where students interested in books, magazines and digital media study with a vast range of industry professionals in lectures and workshops. New York University's Magazine Writing program is a three-semester degree specializing in all aspects of magazine journalism. Cardiff University's School of Journalism, Media and Cultural Studies offers a nine-month MA in Magazine Journalism with an optional extra three months spent on a dissertation. It is an intensive course where students learn practical skills in producing magazine 
journalism, making three issues of their own magazine with current industry software for print and online publications. The focus of all of these courses is primarily vocational, preparing students for careers in the industry. The challenge, it would seem, is for courses to be developed that encompass both a scholarly and a vocational approach.

In 2007, the Department of Media and Communications (part of University of Sydney's School of Letters, Art, and Media) was expanding its postgraduate coursework program, and MEC06914 Making Magazines was developed. At the same time, within the Department of English (also part of the school) ENGL6970 Australian Magazines and Print Culture was offered for the first time. The unit was created by Elizabeth Webby, whose expertise in early Australian literature and colonial print culture is recognized internationally (see, for example, Webby 1988; 2004). Webby retired soon after teaching the unit in 2007, and the unit has changed over time and will soon be re-badged as Reading Magazines to reflect its relationship with Making Magazines. The co-existence of these units within a school, available for students to cross-list, has allowed the mix of scholarly and professional study of magazines within a single degree.

In practical terms, as we foreground in the first section of this paper, the lack of a cohesive international discipline of magazine studies meant that there was no such thing as a recognised tradition of Australian magazine studies when we launched the two units in 2007. And we mean that with no disrespect to pioneering individual Australian scholars who led the way, like Susan Sheridan (see, for example, Sheridan 2002), Frances Bonner and Susan McKay (see, for example, Bonner \& McKay 1998) and Lyndall Ryan (see, for example, Ryan 2001). It is certainly possible to argue that there are a number of prolific feminist academics in Australia who have published a body of work about Australian women's magazines, and it is interesting to map where their work appears. For example, Ryan's 2001 piece about the Australian women's weekly appears in Journal of interdisciplinary gender studies: JIGS. As we have already noted, Holmes writes about the lack of disciplinary coherence in magazine studies, and perhaps this is even more the case in Australia where scholars may identify primarily as feminist, journalism or media studies scholars rather than as magazine scholars. In her doctoral thesis on Australian craft magazines, Rose Williamson locates her study 'theoretically and methodologically within the field of rhetorical criticism' (2009: 7). Like Williamson, readers of this special issue may teach writing or rhetorical studies (in one form or another) and also have a strong interest in magazines as storehouses of data about Australian everyday life and popular culture. Of course, readers of TEXT likely identify as writing or communication specialists who may have an interest in magazines as collections of fiction and non-fiction writing and so understandably (for literary scholarship) but perhaps problematically (for magazine scholarship) 'cherry pick' literary or other content. Individual scholars will feel very strongly about how they categorise their work and most will see themselves as specialists in more than one field, but we do not think this lessens the need for discussions of this nature about our discipline; quite the opposite, in fact. 
Abrahamson describes isolated pieces of scholarship about magazines as 'Brilliant fragments' (1995) and we think this describes very aptly the feeling we had - in the early years teaching magazine studies especially - trying to locate and then gather the gems together and really make them shine for our students. There are no introductory texts as there are in other fields, such as Journalism Studies, Cultural Studies, Media Studies, Literary Studies, Film Studies, Television Studies, Radio Studies, Sports Studies and Celebrity Studies. If we were working on magazines historically, in the modernist or Victorian periods, we would be overwhelmed by the amount of scholarship. Just as we could be overwhelmed by the scholarship on women's magazines, especially from a feminist perspective, from any period since the first women's magazine appeared in London in 1693, The Ladies mercury. As our research and teaching are not limited to Australian magazines, or to women's magazines, we found ourselves searching a huge range of journals for reading lists.

It was particularly difficult to find relevant scholarly material in the first year ENGL6970 was offered and so we cobbled together a fairly slim reader (a collection of chapters and journal articles). John Tregenza's Australian little magazines 192319541964 and Bruce Bennett's Cross currents: magazines and newspapers in Australian literature (1981) saved the day regarding the history of newspapers and 'little magazines', but obviously that material is now dated and their remit did not include popular magazines. Williamson points to Frank S Greenop's History of magazine publishing in Australia (1947) as a promising start to scholarship on Australian magazines but notes that there have been no other comprehensive published studies since which incorporate both popular magazines and literary ones (2009: 11). Often it was illustrated 'coffee table' books like Vane Lindsay's The way we were (1983) that proved helpful when making a case that there were other magazines apart from the Bulletin and the Weekly and indeed that there was such a thing as a history of Australian popular magazines. In the second year ENGL6970 was offered in 2009, two excellent (then) new books about Australian publishing served as a good introduction to the history of Australian literary and print culture: Paper empires: a history of the book in Australia 1946-2005 (Munro \& SheahanBright 2006) and Making books: contemporary Australian publishing (Carter \& Galligan 2007). As their titles suggest, however, their focus is very much on book publishing rather than magazines, but these texts at least mentioned newspapers and literary magazines, if not glossies. In 2014, there is now ample material for a course reader and a growing list of readings available electronically in the University of Sydney's Fisher Library which demonstrates that Australian magazine studies is a healthy (if nascent) area of scholarship and one with many opportunities for emerging scholars working in disciplines as diverse as gender and cultural studies, media and communication, English, writing and rhetorical studies.

Since updating the ENGL6970 unit description and refocusing on more contemporary print and digital magazines, the unit now privileges mainstream women's and men's popular glossies rather than literary journals exclusively. We have moved from a focus on 'little magazines' to magazines more generally. Accordingly, scholarship by second-wave feminist scholars, like Betty Friedan's critique of women's magazines in Feminine mystique (1963), and third-wave scholars, like Naomi Wolf's chapter on 
'Culture' in The beauty myth (1990), has been incorporated. Feminist scholarship has certainly led the way in magazine studies, with Marjorie Ferguson's Forever feminine (1983), Janice Winship's Inside women's magazines (1987), Anna Gough-Yates' Understanding women's magazines (2003) and Joke Hermes' Reading women's magazines (1995) all making major contributions to the field. They have been invaluable, but as ENGL6970 is not a feminist or gender studies unit but an English one taken primarily by creative writing, media (publishing) and literature students, one cannot assume that that a feminist lens will suit all students. However, in 2014 we can make an argument that the discipline is a much more wide-ranging one that it was even seven or eight years ago. Journal articles by Margaret Henderson (1999), Douglas Booth (2008) and Garrie Hutchinson (1998) (sport writing and surfing magazines), Roger Osborne (2007) and Patrick Buckridge (2002) (literary magazines and literary content in magazines), Ross Laurie (1998; 1999) (men's magazines), Raelene Wilding (2006) (wedding magazines), Christy Newman (2005) (health magazines) and Rosemary Williamson (2010) (craft magazines) have helped broaden the perspective and fill in the gaps, and so it has been possible to collate enough material for a much more comprehensive course reader and a library reserve list of articles that now respond to earlier Australian magazine scholarship. Katherine Bode and Robert Dixon's work in digital humanities adds another exciting element to scholarship about publishing trends more broadly (2009). The AustLit magazine database (discussed by Kilner in this special issue) and national resources like TROVE have also been tremendously helpful resources and have enlivened Australian scholarship in magazines and print culture. To date, JAS (Journal of Australian studies) and Continuum have been the most fertile Australian journals for material about magazines but the occasional article in Australian feminist studies (see Le Masurier 2007), Australian journal of communication (see Bonner \& McKay 2002) and TEXT (see Williamson 2008) have also contributed to the field. TEXT's coverage of creative non-fiction writing, with the 2013 special issue devoted to nonfiction, also strengthens the body of Australian scholarship related to - and indeed sometimes conflated with - magazine studies. The fact remains, however, that there is no Australian version of, or even an English language equivalent to, the Dutch journal Magazine for magazine studies.

The experience of teaching and designing the curriculum for MECO6914 Making Magazines was different. The original iteration of MECO6914 was far too ambitious and far too scholarly for a one-semester unit. The brief for the unit was to teach students the key skills they would need for working in magazine production. There was simply not enough time to incorporate scholarly and practical content. After the first trial of the unit, the scholarly material was pared back and the focus shifted to the practical elements of making a magazine. This was also a response to student feedback. The practical hands-on 'making' was what they wanted. Students work in small groups to conceive, plan and produce all the content for an original magazine. It can be about anything, which is particularly good for international students, many of whom are from China where the magazine industry is booming, so they can draw on their own culturally specific knowledge. Students have to research the market and competition and devise a concept and 'editorial philosophy' that responds to the needs or desires of an actual readership demographic. They learn the basics of writing 
different genres of feature journalism, which complements skills they learn in other writing-based units of study in the degree. The students conceptualise stories as visual as much as written media. This means understanding the importance of images and graphic design. Initially, we incorporated four weeks of InDesign software training into the unit, but now there is a pre-requisite unit, MECO6930 Publication Design, corun with Sydney College of the Arts, which teaches the basics of graphic design and InDesign, the industry-favoured software. By the end of the semester, the students have produced a magazine in PDF and print, with a blog, and using social media as marketing tools. There was still a concern however that the more scholarly side of magazines was being overlooked. This is where a complementary unit of study comes into its own.

In the first iteration of ENGL6970, as was the case in most English postgraduate coursework units at our university at the time, students gave a short oral presentation and wrote a long research essay about a magazine of their choice and had the choice of answering one of a number of questions (or devising their own research question). Suggested topics included: the relationship between the parent (British) culture and Australian colonial print culture; the influence of the Bulletin; censorship; the Ern Malley affair; ${ }^{2}$ public libraries; literary awards and prizes; little magazines like Meanjin and Quadrant; sports writing; and representations of women in consumer magazines. The diversity of the material illustrates very clearly Latham and Scholes' point that 'periodical studies' is a fascinating and extremely diverse discipline but, understandably, it was a daunting task for both local and international students to familiarise themselves with the historical material and the range of topics in just one semester. This was also the case for students in a fourth-year undergraduate unit called MECO3609 Critical Practice, where Le Masurier runs a magazine research cluster of some 25 students. The students devise an original research question about magazines and produce a 5,000-word essay. The topics are fascinating but students often come up against the sheer lack of scholarly material to help them conduct the necessary research. It is a challenge to help them situate their work within a field of study, to engage in dialogue with magazine scholars about key problematics or questions that we could if we were working in, say, journalism studies.

The rapidly changing digital technologies have also complicated the pedagogy of these units of study. Scholars were starting to make better use of digital archives and resources, and the digital humanities emerged at the same time that magazines and newspapers were incrementally and tentatively embracing digital crossovers and even stand alone digital publications. In 2009 in ENGL6970, there was more emphasis on collaboration, with an increased weighting for seminar leadership and peer review. The essay questions were similar but by that time also included options to write about online magazine forums, and there was more emphasis on the relationship between images and text. Students were grappling with how to assemble the toolbox of skills needed to unpack a magazine without forgetting that the 'package' and how it is wrapped is what makes a magazine different to other texts. As Holmes and others have noted, it is the presentation that makes them difficult to 'read' and write about (2007: 511). There was a need to remind students about the relationship (often a disjunction) between magazine images and the message conveyed in the written text. 
Possibly, it is that literature students are accustomed to 'close reading' and need to be reminded to read the images and meta-textual elements too, but it is another example of the challenge that we face as scholars in a field that demands a multi-disciplinary approach no matter what our disciplinary 'home'. This also alerts us to one of the challenges of magazine studies and its crossover with literary studies, which we all need to be aware of as teachers of writing. As Latham and Scholes note, we need to be wary of what they call 'the hole in the archive' where, for example, literary pages from magazines are preserved and archived but the advertising and all of the other metatextual material are not (2006: 520). As they point out, even if we do take advertisements as objects of study, we need to consider how can they be preserved digitally and then tagged for searches, and so there are very practical matters for us to consider in addition to questions about disciplinary boundaries (Latham \& Scholes 2006: 521). Unsurprisingly, literary scholars are interested in the literary content of magazines: the short stories, serials and poems. Those of us who teach feature writing or creative non-fiction are interested in the 'journalism'. It may be useful to think about the practical consequences of this 'hole' and how it may affect the way both we and our students approach magazines as objects of study.

At that time, it was not only archives that were embracing digital technologies, for the concept of 'print-only' was rapidly becoming outdated as digital publishing and hybrid texts beckoned. In one class discussion in 2009, students shared their predictions for digital publishing and what this might herald for magazines and for print culture in Australia more generally. One local student gave a memorable presentation about a mysterious object rumoured to be called a 'Kindle' (second generation 'international' Kindles only became readily available in Australia in October 2009). An Italian student shared his experiences reading a micro-narrative on his mobile phone (the first generation of iPhones became available in 2007 but it was several years before they became ubiquitous in Australia). Smart phones and tablets were on the horizon but we had no real understanding of what they might look like or how they would revolutionise reading practices. Looking back on the changes since then, it is as if this was fifty years ago rather than four or five. In discussions about the research essay component, however, it was evident that the students needed more help with methodology and exactly what constitutes 'research' in a unit badged as being magazine and print culture studies. As we have already noted, Johnson argues that, on top of all of the other challenges magazine scholars need to contend with, the fact that industry research is rarely available to academics and students is a major impediment (2007: 523). Given this deterrent, our students deserve praise for their willingness to think creatively about the research and writing process. By Winter School 2012, the unit description for ENGL6970 had been updated and so had the outline to reflect the changing face of publishing and an increased emphasis on glossies and custom magazines, and it was at this time that the unit narrowed in focus and became more obviously about magazines rather than periodicals. Most of us had tablets and smart phones in class and discussion about the crossover between digital and print environments formed a part of every seminar. Many more 'hands on' activities were introduced into seminars, and reading and research methodologies were discussed in more detail. As an alternative to the essay, in second semester 2013, ENGL6970 students had the option of writing a Storify narrative or a feature article. This went 
some way to making the tasks more engaging and strategically aligned to the content, but more innovation is required in Winter School 2014.

There remain challenges in teaching Australian magazine studies to local and international students. Firstly, the lack of resources about glossy magazines in particular - if students cannot find Wikipedia entries (or more than a 'stub') for significant Australian magazine editors or any reference at all to popular magazines published before 1950, then it is sometimes an uphill battle engaging them with Australian magazine scholarship. This absence of material, especially about female editors and journalists, is a particular concern (but we hope that interest garnered by the two Paper giants $(2011,2012)$ television programs helps fill this vacuum). This is yet another gap/'hole' that needs to be filled in Australian magazine studies but, as noted in the introduction to this special issue, a number of biographies and autobiographies have been devoted to recent magazine editors if not colonial ones and inevitably this means more material will filter online. It is especially important that our international students are able to do quick online searches to familiarise themselves with Australian magazine culture and some of the iconic figures that populate it. Moreover, in 2014 and post-ACP (Australian Consolidated Press), we cannot assume that even local students will pick up on casual references to 'Ita', 'Nene' or 'Packer' and automatically understand their role in Australian print history. As Latham and Scholes remind us, digital archives are revolutionising teaching and scholarship in our discipline, and we would add wikis and 'enthusiast' (nonacademic) websites to that category (2006: 519-20). We need to nurture interest in our discipline (and female contributions in particular) via forums like Wikipedia before we can expect students to be engaged enough to tackle online databases like Austlit and other digital archives. One way to address this would be to ask students to create a website or write a Wikipedia entry instead of an essay. ${ }^{3}$ In this way, students could enjoy the liberation of writing a research piece that is not an essay, add to the body of scholarship about Australian magazines and make a valuable contribution to the popularisation of Australian magazine studies. We have to remind ourselves that for most of our students even the Bulletin is an historic artifact rather than a part of their lived culture, and we need to inspire their interest in bringing our magazine cultural history to life.

\section{Conclusion}

We need to remain excited about teaching magazine studies and open to new ways of thinking about teaching and scholarship in this fascinatingly diverse field. Writing this essay has prompted us to consider looking more broadly to our colleagues in disciplines like history, gender and cultural studies, and rhetorical studies and perhaps to start conversations with them about further cross-disciplinary collaborations. As Latham and Scholes remind us: 'That a single issue of a magazine offers something of interest to researchers in a wide array of disciplines, including art, literature, law, history, and sociology, suggests how limiting a traditional disciplinary frame might be' (2006: 530). It is our hope that this wide-ranging discussion of the joys and challenges of teaching magazine studies in an Australian university helps inspire other 
TEXT readers to engage in magazine scholarship and to share their experiences teaching writing units that incorporate elements of magazine studies. As this special issue demonstrates, that could range from databases and digital humanities to how to write a feature article. We wonder whether one way forward for those of us tentatively carving out a space for magazine studies is to embrace that sense of imagined community that is so often identified in glossy magazines and women's magazines in particular? In having this dialogue about teaching magazine studies, perhaps we may encourage others to join us and extend this two-way conversation into a broader discussion.

\section{Acknowledgements}

We would like to thank our students, who have so generously helped us work through what Australian magazine studies might look like. We would also like to thank the two blind reviewers who contributed such helpful suggestions regarding structuring this piece.

\section{Endnotes}

1. Carolyne Lee and Jennifer Martin's essay in this special issue is evidence that magazine feature writing is taught as part of that program.

2. An infamous Australian literary hoax by James McAuley and Harold Stewart, who sent in a suite of poems supposedly written by Ern Malley, but only found after his death by his sister who then sent them to the modernist magazine Angry penguins in 1943. The editor Max Harris lauded the poems and then was humiliated when the hoax was revealed and the young men boasted that they concocted the nonsensical poems in one day.

3. Indeed, other colleagues, like Frances di Lauro (academic writing, see di Lauro \& Shetler 2013) and Stuart Fraser (medical sciences), have already designed similar assessment tasks.

\section{Works cited}

Abrahamson, D 1995 The American magazine: Research perspectives and prospects, Ames: Iowa State University Press

Abrahamson, D 2007 'Magazine exceptionalism: The concept, the criteria, the challenge' Journalism Studies 8: 4, 667-70

Bennett, B 1981 Cross currents: Magazines and newspapers in Australian literature, Melbourne, Vic: Longman Cheshire

Bode, K \& Dixon, R (eds) 2009 Resourceful reading: The new empiricism, eresearch and Australian literary culture, Sydney: Sydney University Press

Bonner, F \& McKay, S 1998 'Caring for the family: Fifty years of health in the Australian Women's Weekly' Journal of Australian Studies 59, 154-64

Booth, D 2008 '(Re)reading the surfer's Bible: The affects of Tracks' Continuum 22: 1, 17-35

Buckridge, P 2002 “'Good reading” in the Australian women's weekly, 1933-1970' JASAL 1, 32-43

Carter, D \& Galligan, A (eds) 2007 Making books: Contemporary Australian publishing, St Lucia, Qld: U Queensland P

Cochrane, T \& Narayan, V 2013 'Mobile social media: Productivity and presentation tools for the $21^{\text {st }}$ century teacher', HERDSA conference 1-4 July 2013, Auckland, New Zealand: AUT 
Conboy, M 2004 Journalism: A critical history, London: Sage

Damon-Moore, H 1994 Magazines for the millions: Gender and commerce in the Ladies' home journal and the Saturday evening post, 1880-1910, Albany: State U of New York P

Deuze, M 2005 'What is journalism? Professional identity and ideology of journalists reconsidered' Journalism 6: 4, 442-64

Di Lauro, F \& Shetler, A 2013 'Writing with Wikipedia: Building ethos through collaborative academic research', in KE Pytash, RE Ferdig \& TV Rasinski (eds) Preparing teachers to teach writing using technology, Pittsburgh: ETC P, 209-23

Ferguson, M 1983 Forever feminine: Women's magazines and the cult of femininity, London/Exeter (NH): Heinemann

Friedan, B 1965 c1963 The feminine mystique, Harmondsworth: Penguin

Gough-Yates, A 2003 Understanding women's magazines, London: Routledge

Greenop, FS 1947 History of magazine publishing in Australia, Sydney: KG Murray

Hartley, J 1996 Popular reality: Journalism, modernity, popular culture, London \& New York: Arnold

Hartley, J 1999 'What is journalism? The view from under a stubbie cap' Media International Australia, Incorporating Culture \& Policy 90, 15-33

Hartley, J 2000 'Communicative democracy in a redactional society: The future of journalism studies' Journalism 1: 1, 39-47

Henderson, M 1999 'Some tales of two mags: Sports magazines as glossy reservoirs of male fantasy' Journal of Australian Studies 62 (September), 64-75

Hermes, J 1995 Reading women's magazines: An analysis of everyday media use, Cambridge: Polity

Holmes, T 2007 'Mapping the magazine' Journalism Studies 8: 4, 510-21

Hutchinson, G 1998 'Playing (and writing) our own games: Sportswriting and sports journalism in Australia' Journal of Australian Studies 58 (September), 84-98

Huyssens, A 1986 After the great divide: Modernism, mass culture, postmodernism, Bloomington: Indiana University Press

Johnson, S 2007 'Why should they care?: the relationship of academic scholarship to the magazine industry' Journalism Studies 8: 4, 522-28

Kilner, K 2014 'Austlit and Australian Periodical Studies', TEXT, Special issue 25, April, at http://www.textjournal.com.au

Latham, S \& Scholes, R 2006 'The rise of periodical studies' PMLA 121: 2, 517-31

Laurie, R 1998 'Fantasy worlds: The depiction of women and the mating game in men's magazines in the 1950s' Journal of Australian Studies 56, 116-24

Laurie, R 1999 'Masculinities and war comics' Journal of Australian Studies 60, 114-21

Lee, JY 2005 'From the field: The future of American periodicals and American periodicals research' American Periodicals: A Journal of History, Criticism, and Bibliography 15: 2, 196-201

Le Masurier, M 2007 'My other, my self: Cleo magazine and feminism in 1970s Australia' Australian Feminist Studies 22: 53, 191-211

Lindesay, V 1983 The way we were: Australian popular magazines 1856-1969, Melbourne, Vic: Oxford UP

McCracken, E 1993 Decoding women's magazines: From 'Mademoiselle' to 'Ms', London: MacMillan

McRobbie, A 1999 'More! New sexualities in girls' and women's magazines', in A McRobbie The

Culture Society: Art, Fashion and Popular Music, London: Routledge, 46-61 
Munro, C \& Sheahan-Bright, R (eds) 2006 Paper empires: A history of the book in Australia, 19462005, St Lucia, Qld: U Queensland P

Newman, C 2005 'Healthy, wealthy and globalized? Reader letters to Australian Men's health magazine’ Continuum 19: 2, 299-313

Osborne, R 2007 'Behind the book: Vance Palmer's short stories and Australian magazine culture in the 1920s' JASAL 6, 49-64

Paper giants: The birth of Cleo 2011 Australia: Australian Broadcasting Corporation: Roadshow Entertainment [distributor]

Paper giants: Magazine wars 2012 Australia: Australian Broadcasting Corporation: Roadshow Entertainment [distributor]

Philpotts, M 2012 'The role of the periodical editor: Literary journals and editorial habitus' The Modern Language Review 107: 1, 39-64

Pykett, L 1989 'Reading the periodical press: Text and context' Victorian Periodicals Review 22: 3, 100-08

Ryan, L 2001 'A turning point for the "Weekly" and a turning point for women?: The debate about women and university in the Australian women's weekly in 1961' Journal of Interdisciplinary Gender Studies: JIGS 6: 1, 52-65

Sheridan, S 2002 Who was that woman? The Australian women's weekly in the postwar years, Sydney: UNSW UP

Steinem, G 1994 Moving beyond words, New York: Simon \& Schuster

The Digital Archives Hub, at http://www.pulpmags.org/archives_hub.html

Tregenza, J 1964 Australian little magazines 1923-1954: Their role in forming and reflecting literary trends, Adelaide, SA: Libraries Board of South Australia

van Zoonen, L 1998a 'A professional, unreliable, heroic marionette (M/F): Structure, agency and subjectivity in contemporary journalism' European Journal of Cultural Studies 1: 1, 123-42

van Zoonen, L 1998b 'One of the girls? The changing gender of journalism', in C Carter, G Branston \& S Allen (eds) News, gender and power, London: Routledge, 33-46

Webby, E 1988 'Writers, printers, readers: The production of Australian literature before 1855', in L Hergenhan (ed) The Penguin new literary history of Australia, Ringwood: Penguin, 113-25

Webby, E 2004 'Images of Europe in two nineteenth-century Australian illustrated magazines' Victorian Periodicals Review 37, 10-24

Wilding, R 2006 'Locating editorials and advertising in wedding magazines' Media International Australia, Incorporating Culture \& Policy 119, 74-84

Williamson, R 2008 'The case of the writer, the academic and the magazine', TEXT: The Journal of the Australian Association of Writing Programs 12: 1, at http://www.textjournal.com.au/april08/williamson.htm (accessed 24 March 2014)

Williamson, R 2009 'Crafting the creative life: The rhetorical dimensions of selected Australian quilters’ magazines 1988-2005, PhD dissertation, Armidale: U of New England

Williamson, R 2010 'Buying the creative life: The rhetorical function of Australian quilters' magazines as advocates of choice', Media, Democracy and Change: Refereed Proceedings of the Australian and New Zealand Communication Association Conference, 2010, at http://www.anzca.net/conferences/pastconferences/94-anzca10proceedings.html (accessed 24 March 2014)

Winship, J 1987 Inside women's magazines, London \& New York: Pandora

Wolf, N 1990 The beauty myth, London: Vintage 
Yale University Library, British and American Digital Periodicals, at http://guides.library.yale.edu/periodicals 